\title{
Approaches for Eliminating Bacteria Introduced during In Situ Bioleaching of Fractured Sulfidic Ores in Deep Subsurface
}

\author{
Hendrik Ballerstedt ${ }^{1, a}$, Eva Pakostova ${ }^{2, b}$, D. Barrie Johnson ${ }^{2, c}$ \\ and Axel Schippers ${ }^{1, \mathrm{~d}^{*}}$
}

\author{
${ }^{1}$ Federal Institute for Geosciences and Natural Resources (BGR), Hannover, Germany \\ ${ }^{2}$ University of Bangor, Bangor, Wales, UK \\ aHendrik.Ballerstedt@iamb.rwth-aachen.de, be.pakostova@bangor.ac.uk, \\ cd.b.johnson@bangor.ac.uk, daxel.schippers@bgr.de
}

Keywords: In Situ leaching; bioleaching; inhibition; subsurface; acidophiles; decommissioning

\begin{abstract}
The major objective of the EU Horizon 2020 project "BioMOre" is the technical realization of indirect in situ leaching of Kupferschiefer sandstone and black shale ore by a ferric iron lixiviant generated by a mixed culture of autotrophic, acidophilic, iron-oxidizing bacteria and archaea in a ferric iron-generating bioreactor (FIGB). These organisms could colonize the deeply buried geological formations even under anaerobic conditions as most are able to grow by coupling the reduction of ferric iron to the oxidation of reduced sulfur compounds in the absence of oxygen. Development of an inhibition protocol to eliminate these allochthonous microbial bioreactor populations subsequent to the completion of in situ bioleaching was therefore investigated. Column bioleaching experiments using a laboratory-scale FIGB confirmed not only that metals were solubilised from both the sandstone and shale ores, but also that significant numbers of bacteria were released from the FIGB. The efficacy of 13 different chemical compounds in inhibiting microbial iron oxidation has been tested at different concentrations in shake flask and FIGBcoupled columns. Iron-oxidation activity, microcalorimetrically-determined activity and ATP measurements, in combination with microscopic cell counts and biomolecular analysis (T-RFLP, qPCR), plate counts and most-probable-number (MPN), were used to monitor the inhibiting effects on the acidophiles. Complete inhibition of metabolic activity of iron-oxidizing acidophiles was achieved in the presence of $0.4 \mathrm{mM}$ formate, $300 \mathrm{mM}$ chloride, $100 \mathrm{mM}$ nitrate, $10 \mathrm{mM}$ of primary $\mathrm{C}_{6}$ to $\mathrm{C}_{8}$ alcohols, $100 \mathrm{mM}$ 1-butanol, $100 \mathrm{mM}$ 1-pentanol, $0.1 \mathrm{mM}$ SDS or $0.35 \mathrm{mM}$ benzoic acid. No inhibition was found for $0.6 \mathrm{mM}$ acetic acid and $200 \mathrm{mM}$ methanol. Based on these results a recipe for the chemical composition of the "decommissioning solution" is proposed.
\end{abstract}

\section{Introduction}

A major concern of deep in situ bioleaching of mineral ores is that facultatively anaerobic acidophiles that couple the oxidation of reduced sulfur compounds to the reduction of ferric iron, inadvertently introduced into buried geological formations from surface-located ferric irongenerating bioreactors (FIGB) could persist and possibly change the environmental conditions in the deep subsurface (e.g. acidification, (heavy)metal ion mobilization) and the composition and metabolic potentials of indigenous microbial communities for long after the biomining operation has finished. To minimize the aftermath of deep in situ bioleaching, it is necessary to prevent metabolic (oxidative/reductive) activities of the microbial catalysts introduced in the in situ leaching lixiviant. This can be achieved by different approaches using various chemical compounds which have been demonstrated to be effective against autotrophic iron-oxidizing acidophiles with biocidal (cell death) or bacteriostatic effects, including biocides, surfactants (anionic/cationic), chlorides, quaternary ammonium compounds, organic solvents or even organic compounds like short chain organic acids, amino acids, glucose or peptone. The known susceptibility of these acidophiles to relatively low concentrations of small molecular weight organic acids and chloride suggests that a strategy for eliminating acidophiles from the ore body could be developed that has little or no environmental impact. 


\section{Materials and Methods}

Bioleaching culture and chemical inhibitors. The ferric iron-generating bioreactor culture (FIGB) comprised of 14 acidophilic strains of mesophilic or moderately thermophilic/thermotolerant bacteria and archaea of the genera Acidithiobacillus, Ferroplasma, Leptospirillum, Sulfobacillus, and Acidiphilium. Cultures were inoculated in sterile basal salt (HBS/TE) medium at $\mathrm{pH} 1.4$ [1] supplemented with $50 \mathrm{mM}$ ferrous iron and were incubated at $35^{\circ} \mathrm{C}$ on a shaker at $120 \mathrm{rpm}$. FIGB was adapted to Kupferschiefer black shale and sandstone ore from Rudna Mine (KGHM, Poland). Chemical compounds presumably effective inhibitors for chemolithoautotrophic iron-oxidizers under acidic conditions, but with limited environmental impact, were chosen.

Inhibitor screening. The efficacy of 13 different chemical compounds at different concentrations for inhibiting iron oxidation by the FIGB microbial community was tested at $35^{\circ} \mathrm{C}$ in $100 \mathrm{~mL}$ narrow neck Erlenmeyer shake flasks, or for volatile inhibiting substances in $120 \mathrm{~mL}$ serum bottles sealed with a butyl rubber stopper, containing $50 \mathrm{~mL}$ or $30 \mathrm{~mL}$ (sealed batches) HBS/TEmedium with $50 \mathrm{mM}$ ferrous sulfate, respectively. The inoculum was $10 \%(\mathrm{v} / \mathrm{v})$ of FIGB-culture. Triplicate inoculated flasks for each concentration of an inhibitor were used. Biological controls (no inhibitor added) and a non-inoculated flask per concentration served as controls. Samples were regularly taken to measure $\mathrm{pH}$, redox potential, ferrous and ferric iron concentrations, and cell numbers.

Inhibitor effect on microbial activity. For the measurement of the reaction heat output by microcalorimetry $\left(\mathrm{T}: 35^{\circ} \mathrm{C}\right.$; TAMIII; TA instruments $\left.[2,3]\right)$ as a general metabolic marker for bioleaching activity and its inhibition, inhibition assays were supplemented with highly pyritic ores (5\% metal-content per batch). After 26 days incubation time the whole volume of each assay was filtered through $0.22 \mu \mathrm{m}$ membrane filters. Aliquots of up to $1 \mathrm{~g}$ of the filter cake were used for microcalorimetric determinations in sealed $4 \mathrm{~mL}$ ampoules.

Column bioleaching experiments. Perspex tubes $(32 \mathrm{~cm}$ long and $9.4 \mathrm{~cm}$ diameter) filled with $2.3 \mathrm{~kg}$ of non-sterile sandstone or black shale ore $(2.0-8.0 \mathrm{~mm}$ diameter $)$ were set up in a temperature-controlled $\left(30^{\circ} \mathrm{C}\right)$ room. Sequential acid and indirect ferric iron leaching (supplied by a FIGB lixiviant) showed a significant copper release from both ores.

At the end of each sequential acid and ferric iron bioleaching, the column was drained, and filled with a $0.5 \mathrm{~L}$ "decommissioning solution" $\left(50 \mathrm{mM} \mathrm{CaCl}_{2}, 300 \mathrm{mM} \mathrm{NaCl}, 300 \mu \mathrm{M}\right.$ formic acid; $\mathrm{pH}$ 3.5). The original decommissioning solution was replaced with a fresh solution of the same composition $(0.5 \mathrm{~L})$ after 3 days. Planktonic microorganisms were enumerated microscopically. Metabolically-active microorganisms were detected on selective solid overlay media [4]. Plates were incubated at $30^{\circ} \mathrm{C}$ and $45^{\circ} \mathrm{C}$ for 10 days, and isolates identified [5,6]. Total active biomass was assessed from ATP contents of ore column effluents, using a bioluminescence assay [7].

A second run of column bioleaching experiments in a modified setup was performed to test the inhibitory effect of a "decommissioning solution" consisting of $0.4 \mathrm{mM}$ formate, $400 \mathrm{mM}$ chloride, $10 \mathrm{mM}$ 1-hexanol, and $0.1 \mathrm{mM}$ sodium dodecyl sulfate (SDS) under aerobic ferrous iron-oxidizing conditions with black shale ore. Two columns were run, one without and one with addition of the "decommissioning solution" 26 days after inoculation with FIGB-culture. The microbial communities were analysed by quantitative real-time PCR (qPCR), total cell counting (SYBR Green staining) and most-probable-number (MPN) cultivation of acidophilic iron-oxidizers as previously described $[3,8]$.

\section{Results and Discussion}

Inhibitor screening in shake flask experiments. The inhibition efficacy of 13 different chemical compounds for iron oxidation under acidic cultivation conditions was tested at different effective concentrations: $20-800 \mathrm{mM}$ chloride, $20-200 \mathrm{mM}$ nitrate, $0.01-0.1 \mathrm{mM}$ sodium dodecyl sulfate (SDS), $0.05-0.4 \mathrm{mM}$ formate, $0.05-0.6 \mathrm{mM}$ acetic acid, $0.07-0.7 \mathrm{mM}$ benzoic acid, 100 and $200 \mathrm{mM}$ methanol, as well as 10 and $100 \mathrm{mM}$ 1-butanol, 1-pentanol, 1-hexanol, 
1-heptanol, and 1-octanol, each. Complete inhibition of the metabolic activity of iron-oxidizing acidophiles was achieved in the presence of $300 \mathrm{mM}$ chloride, $100 \mathrm{mM}$ nitrate, $0.4 \mathrm{mM}$ formate, $0.1 \mathrm{mM}$ SDS, $0.35 \mathrm{mM}$ benzoic acid, $10 \mathrm{mM}$ of primary $\mathrm{C}_{6}$ to $\mathrm{C}_{8}$ alcohols, $100 \mathrm{mM}$ 1-butanol, or $100 \mathrm{mM}$ 1-pentanol. No inhibition was found for $0.6 \mathrm{mM}$ acetic acid and $200 \mathrm{mM}$ methanol. Selected results are shown in Figure 1.

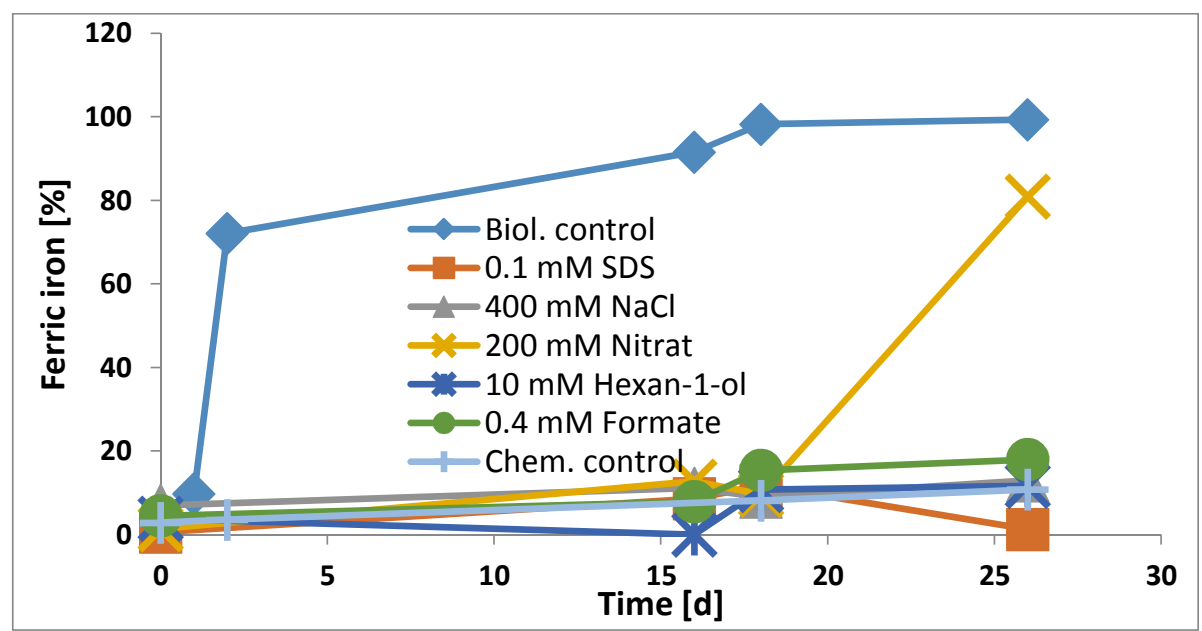

Fig. 1. Comparison of inhibition efficacy of ferrous iron oxidation in assays supplemented with selected inhibitors, biological and chemical controls.

Inhibitor effect on microbial activity. The microcalorimetrically-determined heat output values shown in Figure 2 were in agreement with the iron-oxidation data.

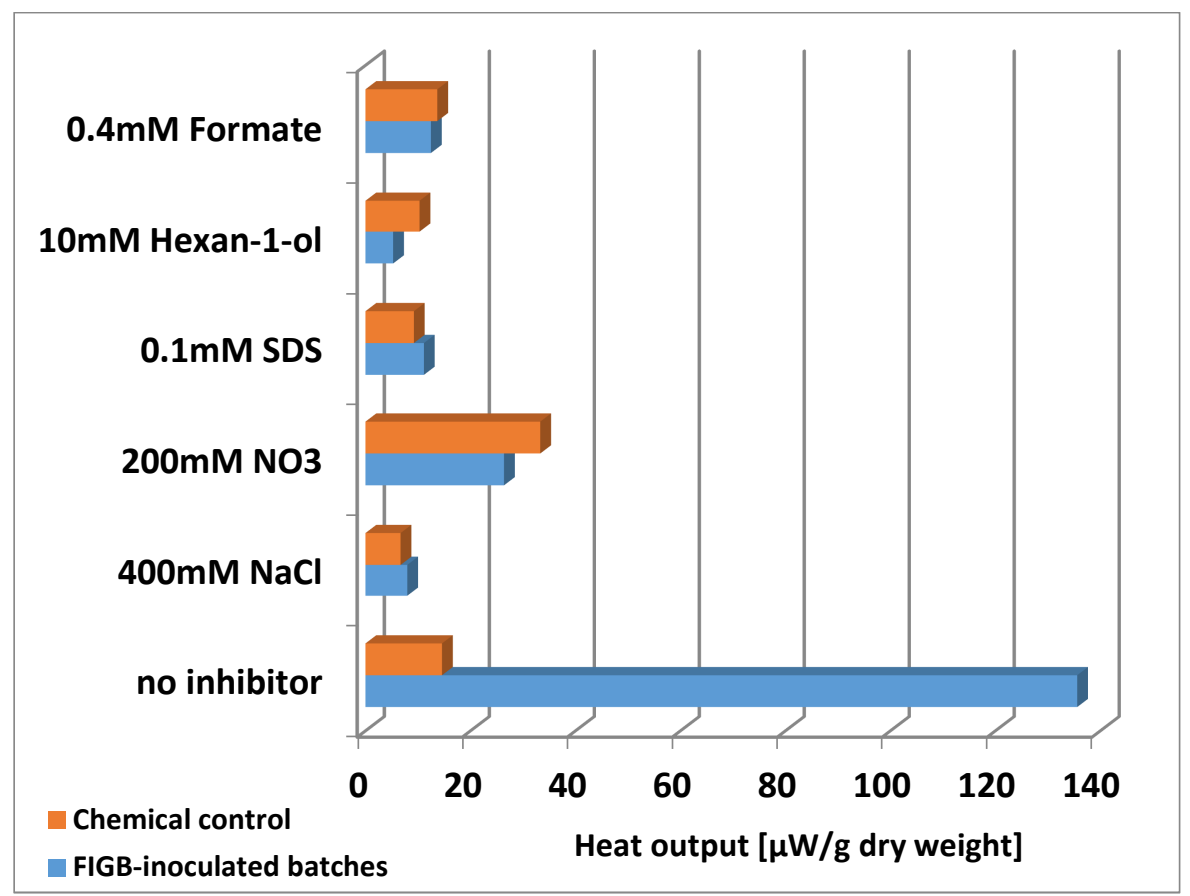

Fig. 2. Microcalorimetric determination of inhibition of microbial bioleaching activity of FIGB on highly pyritic ore.

All assays with added inhibitors, as well as all sterile chemical assays, exhibited low values (besides $200 \mathrm{mM}$ nitrate). Only for the biological control without inhibitor a high thermal output of $136 \mu \mathrm{W} / \mathrm{g}$ pyritic ore was obtained (sterile control $15 \mu \mathrm{W} / \mathrm{g}$ ). The $\mathrm{pH}$-values in all assays were between 1.30 and 1.69 .

Column bioleaching experiments. Column bioleaching experiments have shown that metals are actively released from 'Rudna Mine'- Kupferschiefer sandstone and black shale ores either in the absence of any aeration by chemical dissolution involving ferric iron metals generated in the FIGB 
bioreactor or in presence of molecular oxygen. In the latter case the FIGB-culture was able to colonize both ores. In comparison, less metals were solubilised in non-inoculated chemical control experiments. Inhibition experiments with the "decommissioning solution" at the end of sequential acid/ferric iron leaching of Kupferschiefer sandstone showed that planktonic cell numbers decreased by $25 \%$, and ATP content decreased by $74 \%$ compared with values before simulated decommissioning. The most readily eliminated bacterium was Sulfobacillus (Sb.) thermosulfidooxidans, while Leptospirillum (L.) ferriphilum and Acidithiobacillus (At.) ferridurans were detected after 3 days, but not after 5 days of treatment. In contrast, colonies of $A t$. ferrooxidans were still recovered 6 days after the treatment had begun (not shown).

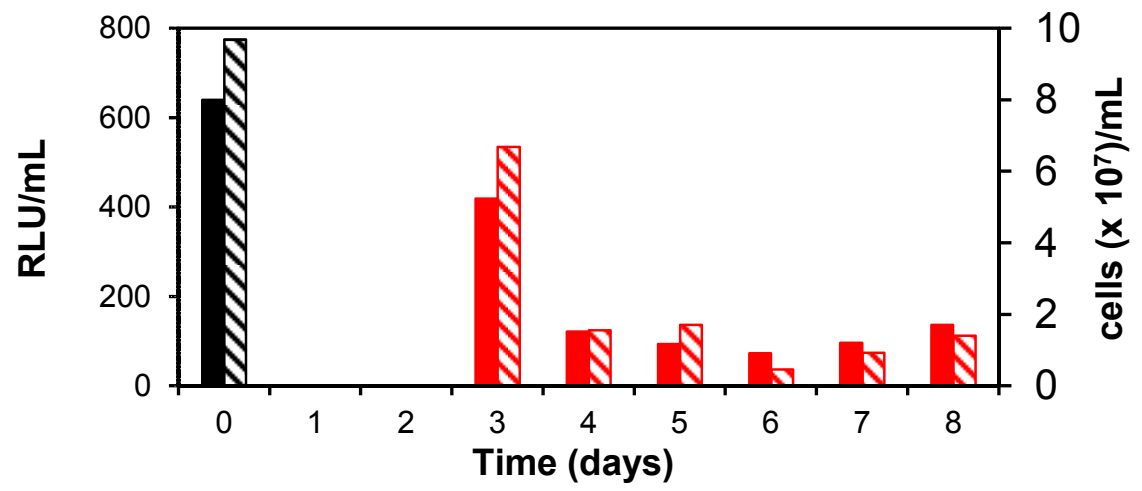

Fig. 3. ATP contents (expressed in relative luminescence units, RLU) (solid columns) and total planktonic cell numbers (hatched columns) in ore column effluents during simulated decommissioning following bioleaching of black shale ore.

Following the same approach but replacing Kupferschiefer sandstone by black shale gave the following results (Figure 3). Planktonic cell numbers decreased by 82 to $95 \%$, and culture ATP content decreased by 79 to $89 \%$, compared to the values before the decommissioning treatment had begun. Once again, L. ferriphilum and Sb. thermosulfidooxidans were successfully eradicated, while on this occasion two species of Acidithiobacillus (At.ferrooxidans and At. ferridurans) and also the heterotrophic iron-reducer $A$. cryptum were detected throughout the entire period of simulated decommissioning (not shown).

The second run of column bioleaching experiments was carried out to test the inhibitory effect of the "decommissioning solution" under aerobic, ferrous iron-oxidizing conditions. After addition of the inhibitory substances on day 26 the copper concentrations declined, whereas they remained fairly constant in the column without added inhibitors. Cell numbers in the liquid phase showed a dramatic decrease in cell numbers after the addition of the inhibitors (Table 1). Most pronounced was this decrease in the numbers of living cultivable iron-oxidizers (by MPN), which represented active cells responsible for copper bioleaching. Total cell numbers (SYBR) and qPCR numbers for the domain bacteria detect DNA of cells which are intact but not necessarily active. Overall the inhibition has shown an efficient decrease of copper bioleaching activity and of the number of metabolically-active iron-oxidizers.

Table 1. Cell numbers $(/ \mathrm{mL})$ in the liquid phase of a black shale-filled bioleaching column before (day 26) and after addition of inhibitory substances (day 46), and in the control column with no added inhibitory substances.

\begin{tabular}{|l|c|c|c|c|}
\hline & $\begin{array}{l}\text { Before inhibition } \\
\text { (day 26) }\end{array}$ & $\begin{array}{l}\text { After inhibition } \\
\text { (day 46) }\end{array}$ & $\begin{array}{l}\text { No inhibition } \\
\text { (day 26) }\end{array}$ & $\begin{array}{l}\text { No inhibition } \\
\text { (day 46) }\end{array}$ \\
\hline $\begin{array}{l}\text { Total cell counts } \\
\text { (SYBR) }\end{array}$ & $1.3 \times 10^{7}$ & $1.7 \times 10^{5}$ & $1.4 \times 10^{7}$ & $1.6 \times 10^{7}$ \\
\hline qPCR Bacteria & $1.6 \times 10^{5}$ & $2.0 \times 10^{2}$ & $5.1 \times 10^{4}$ & $5.0 \times 10^{3}$ \\
\hline $\begin{array}{l}\text { MPN iron- } \\
\text { oxidizers }\end{array}$ & $2.5 \times 10^{7}$ & $9.5 \times 10^{1}$ & $4.5 \times 10^{7}$ & $2.5 \times 10^{7}$ \\
\hline
\end{tabular}




\section{Summary}

Acidophilic microorganisms are known to be sensitive to small molecular weight aliphatic acids, and relatively small concentrations of formic acid (in combination with $\mathrm{NaCl}$ ) were shown to be highly effective at eliminating metal-mobilizing prokaryotes. The inhibition efficacy of 13 different chemical compounds for iron oxidation under acidic cultivation conditions was tested at different effective concentrations in shake flask and column bioleaching experiments. Based on the results a recipe for the chemical composition of a "decommissioning solution" was proposed for the elimination of allochthonous acidophiles after completing deep in situ bioleaching operations.

\section{References}

[1] K. Wakeman, H. Auvinen, D. B. Johnson, Microbiological and geochemical dynamics in simulated-heap leaching of a polymetallic sulfide ore. Biotechnol. Bioeng. 101 (2008) 739750 .

[2] A. Schippers, P.-G, Jozsa, W. Sand, Evaluation of the efficiency of measures for sulphidic mine waste mitigation. Appl. Microbiol. Biotechnol. 49 (1998) 698-701.

[3] A. Schippers, K. Bosecker, Bioleaching: Analysis of microbial communities dissolving metal sulphides, in: J.-L. Barredo (Ed.), Methods in Biotechnology, Vol. 18: Microbial Processes and Products. Humana Press Inc., Totowa, NJ, USA, 2005, pp. 405-412.

[4] D.B. Johnson, K.B. Hallberg, Techniques for detecting and identifying acidophilic mineraloxidising microorganisms, in: D. E. Rawlings D.B., Johnson D.B. (Eds.), Biomining. Springer-Verlag, Heidelberg, 2007, pp. 237-262.

[5] D.B. Johnson, N. Okibe, K.B. Hallberg, Differentiation and identification of iron-oxidizing acidophilic bacteria using cultivation techniques and amplified ribosomal DNA restriction enzyme analysis. J. Microbiol. Methods 60 (2005) 299-313.

[6] C. M. Kay, O.F. Rowe, L. Rocchetti, K. Coupland, K. B. Hallberg, D. B., Johnson, Evolution of microbial "streamer" growths in acidic, metal-contaminated stream draining an abandoned underground copper mine. Life 3 (2013) 189-210.

[7] N. Okibe, D.B. Johnson, A rapid ATP-based method for determining active microbial populations in mineral leach liquors. Hydrometallurgy 108 (2011) 195-198.

[8] S. Hedrich, A.-G. Guézennec, M. Charron, A. Schippers C. Joulian, Quantitative monitoring of microbial species during bioleaching of copper concentrate. Front. Microbiol. 7 (2016) 2044. 